\section{RANCANG BANGUN INDUSTRI PENYAMAKAN KULIT BUAYA SKALA KECIL}

Oleh

Suliestiyah Wrd, Titik Purwati, Purwanti
Anonimus, 1979. Kulit Boks, Standar Industri Indonesia 0018 - 79. Departemen Perindustrian, Republik Indonesia.

Anonimus, 1980. Sepatu Umum Model Pantofel dari Kulit Sistem Lem. Standar Industri Indonesia 0311 - 80. Departemen Perindustrian, Republik Indonesia.

Gustavson, 1956. The Chemistery of tanning process. Academic Press. Inc. Publishers - New York. pp. $308-329$.

O'Flaherty, 1977. The chemistery and Technology of leather. Robert E. Kreiger Publishing Company Huntington, New York (IV). 390.

Penelitian Peningkatan Mutu Kulit Amplas Ringan untuk Atasan Sepatu Dislap ABRI, 1985. Kerjasama Balai Besar Penelitian dan Pengembangan Industri Barang Kulit, Karet dan Plastik dengan Badan Pembekalan Angkat an Bersenjata R.I.

Sharphouse, J.H. 1971. Leather Technician's hand book. Leather Producers' Association, 9 ct. Thomas street London Sei

\section{ABSTRACT}

This paper is prepared for a design of a small scale crocodile skins tanning factory, to produce leather for leather goods.

The capacity of it will be 10 pieces/day wet salted crocodile skins.

This factory will be profitable in the view of techno - economical aspect.

The economocal calculations are as follows : the total capital is fixed capital + working capital Rp.138.149.750,78 the total production cost is variable cost a year + fixed cost a year = Rp.140.115.913,40 the variable cost for a year consists of raw material, packing, chemical/supplement material, electricity and water requirement ; fixed cost for a year consists of labour salaries, maintenance, capital interest, depreciation and general expences ; the manufacturing cost is the total production cost divided by production capacity $=$ Rp.48.651,36/piece .

The profit calculation before taxing is Rp.49.964.086,60 after taxing is Rp.39.971.269,30. The pay out period calculation consists of the percentage of profit to return the capital (rate of return) before taxing is $36,17 \%$ and after taxing is $28,93 \%$ the pay out period before taxing 2 years 8 months, after taxing 3 years 3 months.

The break even calculation consists of the break even point is Rp.77.306.648,33, the percentage of break even point is 40,67 \% and the capacity of break even point is 1.171 pieces. 


\section{I.ATAR BELAKANG PENELITIAN}

Salah satu program pemerintah dalam menambah devisa negara adalah dengan jalan menaikkan ekspor komoditi non migas.

Salah satu komoditi ekspor non migas tersebut yakni komoditi yang dihasilkan oleh Industri Perkulitan.

Kulit reptil merupakan salah satu komoditi ekspor kulit yang cukup mahal harganya.

Dari data yang ada menunjukkan ekspor kulit mentah reptil terus mengalami kenaikan sehingga pada tahun 1985 mencapai nilai US \$225.109 ( $\mathrm{FOB})$.

Dari beberapa jenis kulit reptil (ular, biawak, buaya), kulit buaya merupakan salah satu jenis kulit reptil yang mahal harganya yakni mencapai US \$22.633/kg. (FOB).

Menurut Direktur Jendral Perlindungan Hutan dan Pelestarian Alam, pembinaan industri peternakan buaya saat ini dilakukan meliputi industri penangkaran dan pengolahan kulit buaya dengan fokus utama di Irian Jaya.

Secara nasional maka jumlah buaya yang ditangkarkan adalah sebanyak 6.750 ekor (1985) dan direncanakan akan ditangkarkan sampai 35.000 ekor (1987), dengan produktivitas 7.000 lembar kulit buaya setiap tahun.

Keadaan tersebut akan sangat menunjang kontinuitas penyediaan bahan baku di sektor usaha penyamakan kulit buaya tanpa mengganggu populasi buaya.

Dengan tumbuhnya usaha penyamakan kulit buaya, maka diharapkan pola ekspor kulit mentah buaya akan bergeser menjadi kulit setengah jadi dan kulit jadi, dengan demikian mempunyai nilai tambah yang tinggi sehingga akan menambah devisa negara serta menyerap tenaga kerja yang lebih banyak.

Tujuan penelitian adalah membuat perencanaan pendirian Industri penyamakan kulit buaya skala kecil yang secara ekonomis dapat dipertanggungjawabkan.

*) Kelompok Peneliti Tekno Ekonomi pada Balai Penelitian Barang Kulit.

\section{MATERI DAN METODE PENELITIAN.}

Materi.

Materi yang digunakan dalam penelitian ialah data se kunder yang diambil dari sumber hasil penelitian yang pernah dilakukan oleh BBKKP, serta berbagai buku yang berkait an dengan rancang bangun industri penyamakan kulit buaya skala kecil.

Konversi 1 lembar kulit buaya garaman basah, dengan ukuran lebar $=4,1 \mathrm{~kg}$.

\section{Metode Penelitian.}

Metode yang digunakan, menurut Peter and Thimmerhaus, 1978, untuk mengetahui pabrik agar dapat berhasil dengan baik dapat dengan cara mengetahui :

1. Prosentase nilai batas rugi - laba.

2. Perhitungan pengembalian modal (rate of return).

3. Waktu minimal untuk mengembalikan modal.

\section{HASIL DAN PEMBAHASAN.}

a. Kegunaan dan pemasaran.

Kegunaan : sebagai bahan baku untuk membuat barangbarang dari kulit buaya (tas, dompet, ikat pinggang dan lain-lain).

Pemasaran : kebutuhan dalam negeri dan luar negeri.

b. Spisifikasi produk.

$\mathrm{N}$ a m a : kulit buaya samak krom.

c. Diagram alir kuantitatif.

Diagram alir kuantitatif ini kapasitas produksinya ditrial dan error, peralatan produksi direncanakan terlebih dahulu baru menghitung kapasitas produksinya berdasarkan peralatan yang direncanakan tersebut. 
DIAGRAM ALIR KWANTITATIF

\section{PENYAMAKAN KULIT BUAYA SAMAK KROM}

Kulit Buaya basah garaman

$10 \mathrm{lb} /$ hari $=41 \mathrm{~kg}$.

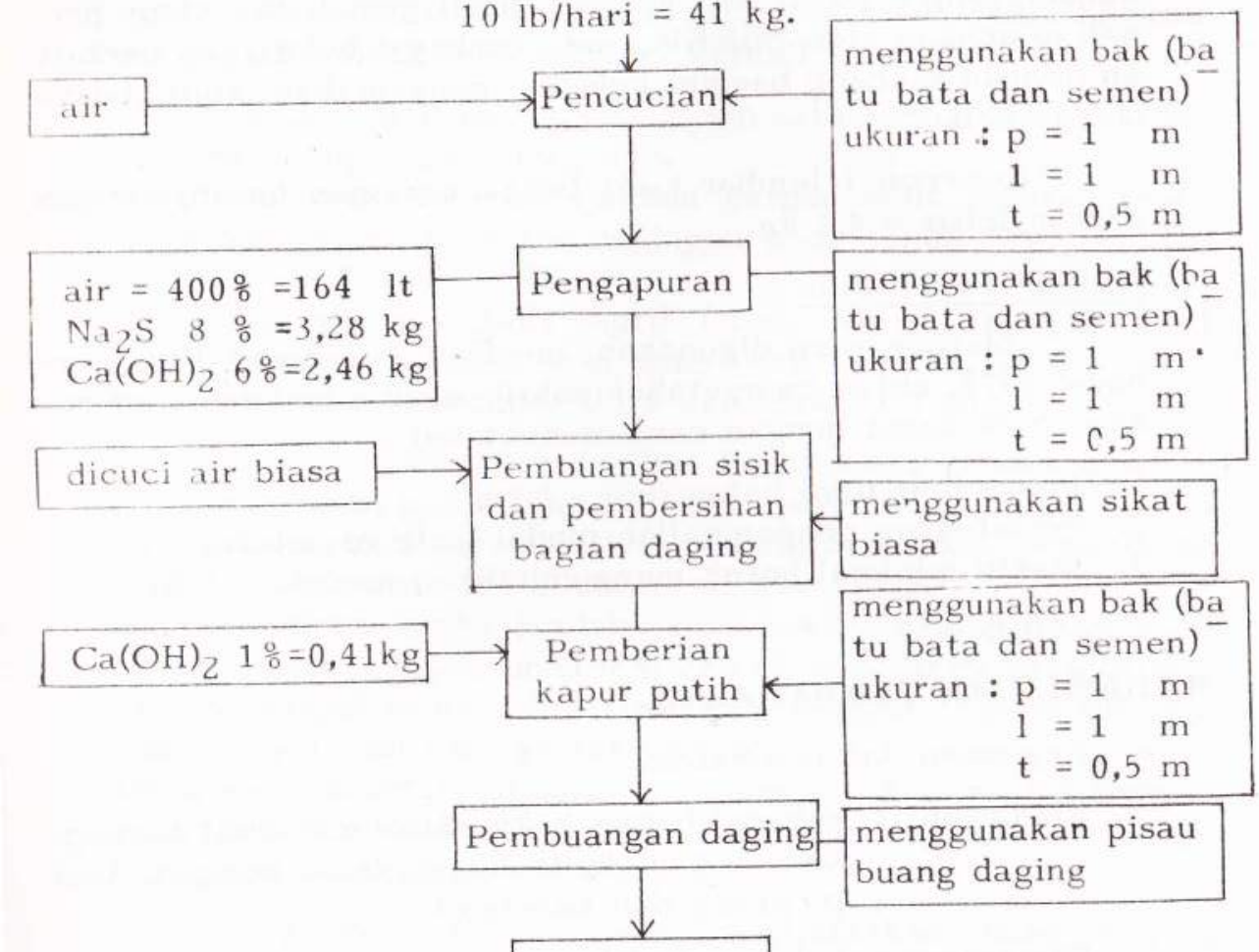

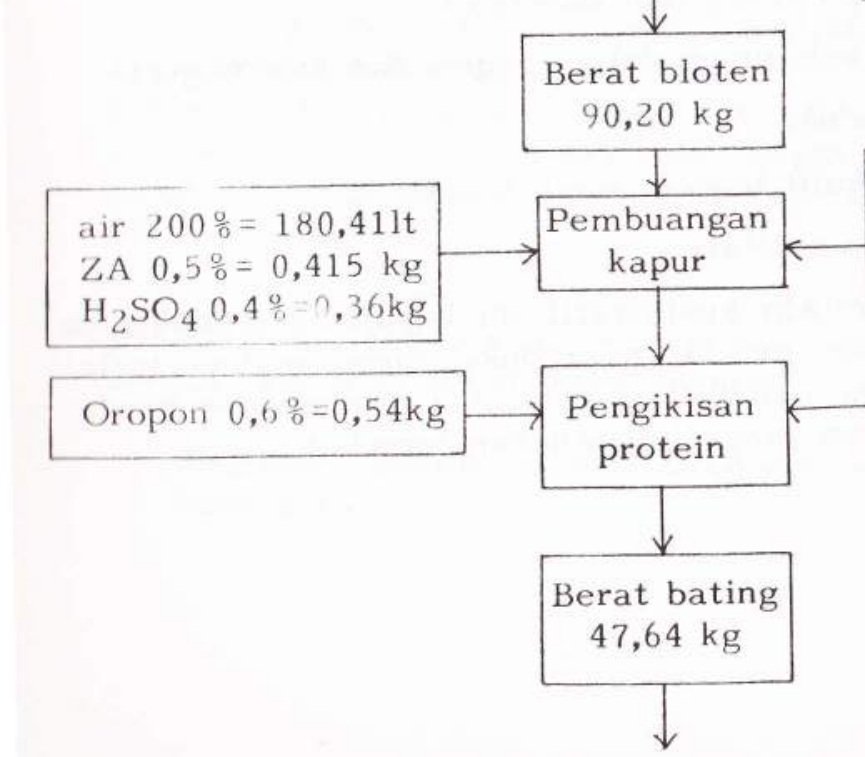

menggunakan bak (ba tu bata dan semen) ukuran : $\mathrm{p}=1 \mathrm{~m}$ $1=1 \mathrm{~m}$ $\mathrm{t}=0,5 \mathrm{~m}$

menggunakan bak (ba tu bata dan semen) ukuran : $\mathrm{p}=1 \mathrm{~m}$ $1=1 \mathrm{~m}$ $\mathrm{t}=0,5 \mathrm{~m}$

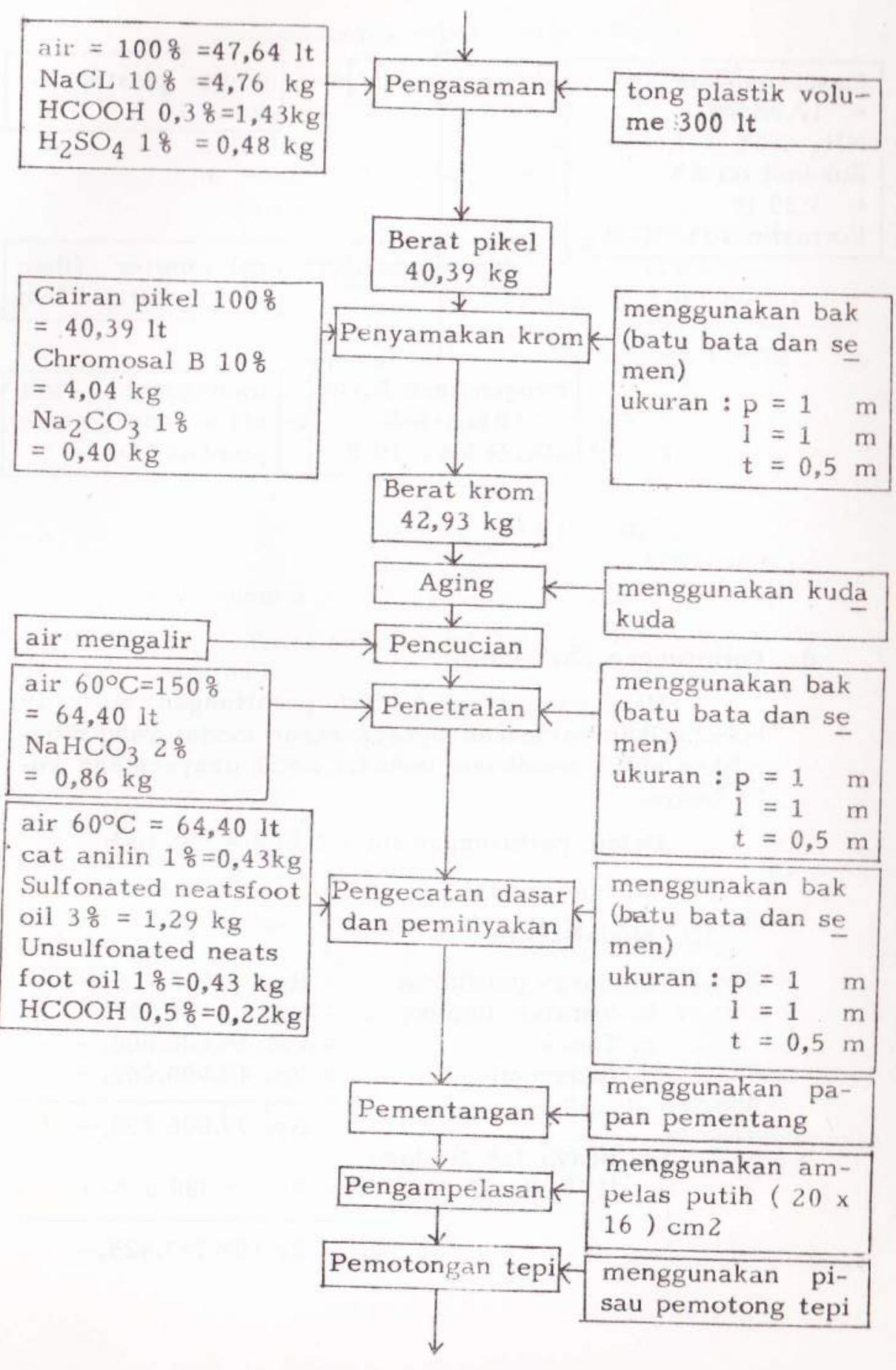




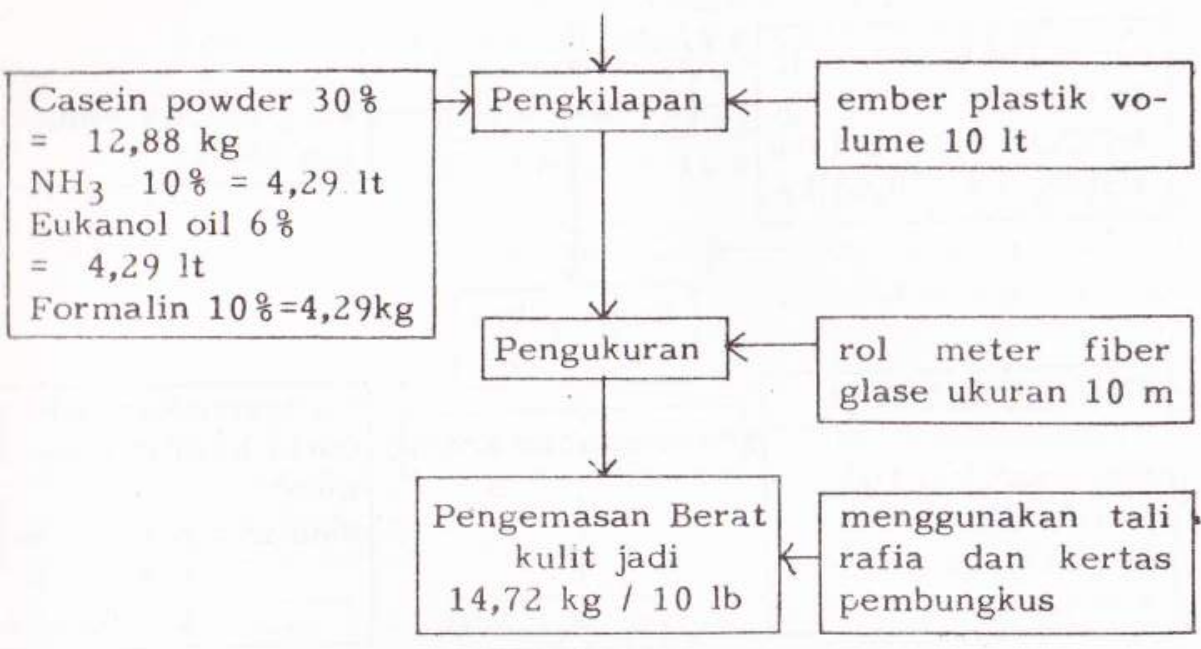

d. Perhitungan Ekonomi.

Hasil yang didapat dari perhitungan ini akan memberikan gambaran berapa besar modal yang dibutuhkan untuk pendirian industri kecil penyamakan kulit buaya.

Dalam perhitungan ini 1 tahun $=288$ hari.

1. Perhitungan modal.

\subsection{Modal tetap}
a. Harga peralatan
$=$ Rp. 3.502.750,--
b. Instalasi listrik
= Rp. 304.000,--
c. Tanah
= Rp. 48.000.000,--
d. Bangunan
$=$ Rp. 48.000.000,--
e. Beaya tak terduga
Rp. 99.806.750,--
$(10 \% \times R p .99 .806 .750)=$ Rp. 9.980.675,--

1.2. Modal tak tetap.

Dihitung untuk modal kerja 3 bulan.
a. Bahan baku
b. Pengemasan
c. Bahan kimia
d. Bahan pembantu proses
e. Listrik
f. Kebutuhan air
g. Gaji

$=$ Rp. $12.960 .000,-$
Rp.
$72.000,--$
$=$ Rp. $12.369 .222,--$
= Rp. $828.000,--$
$=\mathrm{Rp} . \quad 129.103,78$
= Rp. 108.000,--
= Rp. 1.896.000,--

Rp. $28.362 .325,78$
Total modal = Rp.109.787.425,-- Rp. 28.362.325,78
$=$ Rp.138.149.750,78

2. Perhitungan Beaya Produksi

Total beaya produksi diperhitungkan 1 (satu) tahun.

2.1. Beaya tidak tetap.
a. Bahan baku
$=$ Rp. $51.840 .000,--$
b. Pengemasan
= Rp. 288.000,--
c. Bahan kimia
= Rp. 49.476.888,--
d. Bahan pembantu
$=$ Rp. $3.312 .000,-$ proses
e. Listrik
$=$ Rp. $\quad 516.415,48$
f. Kebutuhan air 
2.2. Beaya tetap.
a. Gaji
= Rp. 7.584.000,-

b. Pemeliharaan $3 \% x(b a$ ngunan + peralatan $)=$ Rp. $1.554 .202,50$

c. Bunga modal

$15 \%$ (modal tetap) $=$ Rp. 16.468.113,75

$18 \%$ x modal kerja

3 bulan

= Rp. $5 \cdot 105 \cdot 218,64$

d. Penyusutan

$10 \% \times$ peralatan $=$ Rp. $380.675,--$

$5 \%$ bangunan $=$ Rp. 2.400.000,--

e. Beaya umum

$10 \%$ x gaji

= Rp. $\quad 758.400,--$

= Rp. 34.250.609,89

Beaya produksi total

$=$ Rp.105.865.303,50 $\frac{\text { Rp. } 34 \cdot 250.609,89}{=\text { Rp.140.115.913,40 }}+$

3. Perhitungan Harga Pokok.

Harga Pokok $=\frac{\text { Total beaya Produksi } 1 \text { tahun }}{\text { Jumlah produksi/tahun }}$

$$
\begin{aligned}
& =\frac{\text { Rp.140.115.913,40 }}{2.880} \\
& =\text { Rp. 48.651,36/lembar. }
\end{aligned}
$$

4. Perhitungan Keuntungan

Jumlah produksi per tahun $=288 \times 10$ lembar $=2880$ lembar.

Harga jual = Rp. 66.000,-/lembar.

a. Hasil penjualan per tahun

$\begin{array}{ll}2.880 \times \mathrm{Rp} .66 .000,- & =\mathrm{Rp} .190 .080 .000,-- \\ \text { Total beaya produksi } & =\mathrm{Rp} .140 .115 .913,40\end{array}$

b. Total beaya produksi $=\mathrm{Rp} \cdot 140.115 .913,40$

c. Keuntungan sebelum pajak Rp. 49.964.086,60

d. Pajak perusahaan $20 \%$ = Rp. $9.992 .817,30$

e. Keuntungan sesudah pajak Rp. 39.971.269,30
5. Perhitungan Pengembalian Modal.

5.1 Persen keuntungan untuk mengembalikan modal.

a. Sebelum pajak $=\frac{\text { Keuntungan sebelum pajak }}{\text { seum }} \times 100 \%$

$$
\begin{aligned}
& =\frac{R p \cdot 49 \cdot 964 \cdot 086,60}{R p \cdot 138 \cdot 149 \cdot 750,78} \times 100 \% \\
& =36,17 \%
\end{aligned}
$$

b. Sesudah pajak $=\frac{\text { Keuntungan sesudah pajak }}{\text { pan }} \times 100 \%$ total modal

$$
\begin{aligned}
& =\frac{\text { Rp. } 39 \cdot 971 \cdot 269,30}{\text { Rp. } 138 \cdot 149 \cdot 750,78} \times 100 \% \\
& =28,93 \%
\end{aligned}
$$

5.2. Waktu Pengembalian modal.

a. Sebelum pajak =

$$
\begin{aligned}
& \frac{\text { total modal }}{\text { Keuntungan sebelum pajak + penyusutan }} \times 1 \text { th } \\
& \frac{\text { Rp. } 138.149 .750,78}{\text { Rp.49.964.086,60+Rp.2.780.675 }} \times 1 \text { th } \\
& =\frac{\text { Rp. } 138.149 .750,78}{\text { Rp. } 52.744 .761,60} \times 1 \text { th } \\
& =2 \text { tahun } 8 \text { bulan }
\end{aligned}
$$

b. Sesudah pajak =

$$
\begin{aligned}
& \frac{\text { total modal }}{\text { Keuntungan sesudah pajak }+ \text { penyusutan }} \times 1 \text { th } \\
& \frac{\text { Rp.138.149.750,78 }}{\text { Rp.39.971.269,30+Rp.2.780.675,-- }} \times 1 \text { th } \\
& \frac{\text { Rp. } 138.149 .750,78}{\text { Rp. } 42.751 .944,30} \times 1 \text { th }=3 \text { tahun } 3 \text { bulan }
\end{aligned}
$$

6. Perhitungan batas rugi - laba

$$
\begin{aligned}
& \text { 6.1. Nilai Batas } \\
& \text { Rugi - Laba }
\end{aligned}=\frac{\text { Beaya tetap }}{1-\frac{\text { beaya tidak tetap }}{\text { penjualan }}}
$$




\section{LAMPIRAN.}

1. Bahan baku.

Bahan baku : kulit buaya basah garaman.

Kapasitas produksi : 10 lembar/hari.

Harga kulit buaya basah garaman = Rp.18.000,-/lembar

Kebutuhan bahan baku per tahun :

$288 \times 10 \times \mathrm{Rp} .18 .000,-=\mathrm{Rp} .51 .840 .000,--$

2. Bahan jadi.

Bahan jadi : kulit buaya samak krom.

Harga jual kulit buaya samak Khrom : Rp.66.000,-/lem-

bar.

Penjualan kulit buaya samak khrom per tahun.

$288 \times 10$ × Rp.66.000,- = Rp.190.080.000,--

3. Pengemasan.

Menggunakan kertas pembungkus dan tali rafia.

Kebutuhan pengemasan dalam 1 hari :

8 lembar kertas pembungkus Rp.100,- $=$ Rp. $800,--$

$20 \mathrm{~m}$ tali rafia@ Rp. 10,-

$$
\frac{\text { Rp. 200,-- }}{\text { Rp.1000,-- }}
$$

Jumlah kebutuhan pengemasan dalam setahun :

$288 \times$ Rp. $1.000,--=$ Rp. $288.000,--$

4. Tanah dan bangunan.

a. Tanah

Luas tanah $=480 \mathrm{~m} 2$ @ Rp.100.000,--

Jumlah harga tanah $=$

480 x Rp. $100.000,--=$ Rp. $48.000 .000,--$

b. Bangunan.

Luas bangunan $=240 \mathrm{~m} 2$ @ Rp.200.000,--

Jumlah harga bangunan $=$

240 x Rp. $200.000,--=$ Rp. 48.000.000,--

Jumlah total harga tanah + bangunan

$=$ Rp.48.000.000,- + Rp.48.000.000,- = Rp.96.000.000,Harga diatas tidak termasuk beaya permbuatan su mur, bak penampung air, bak penampung air limbah.
5. Bahan kimia dan pembantu proses.

\begin{tabular}{|c|c|c|c|c|}
\hline No. & Nama Bahan & $\begin{array}{c}\text { Pemakaian/ } \\
\text { hari }\end{array}$ & $\begin{array}{l}\text { Harga } \\
\text { satuan }\end{array}$ & $\begin{array}{l}\text { Jumlah } \\
\text { harga }\end{array}$ \\
\hline 1. & $\mathrm{Na}_{2} \mathrm{~S}$ & $3,28 \mathrm{~kg}$ & $600,-$ & Rp. $1.968,--$ \\
\hline 2. & $\mathrm{Ca}(\mathrm{OH})_{2}$ & $2,87 \mathrm{~kg}$ & 460 ,- & Rp. $1.320,20$ \\
\hline 3. & $\mathrm{ZA}$ & $0,415 \mathrm{~kg}$ & $110,-$ & 45,65 \\
\hline 4. & $\mathrm{H}_{2} \mathrm{SO}_{4}$ & $0,88 \mathrm{~kg}$ & Rp. $\quad 500,-$ & $440,--$ \\
\hline 5. & Oropon & $0,54 \mathrm{~kg}$ & Rp. $3.360,-$ & Rp. $1.814,40$ \\
\hline 6. & $\mathrm{NaCL}$ & $4,76 \mathrm{~kg}$ & Rp. $\quad 100,-$ & $476,-$ \\
\hline 7. & $\mathrm{HCOOH}$ & $1,65 \mathrm{~kg}$ & Rp. $1.500,-$ & Rp. 2.475,- \\
\hline 8. & Chromosal B & $4,04 \mathrm{~kg}$ & Rp. 2.900,- & Rp.11.716,-- \\
\hline 9. & $\mathrm{Na}_{2} \mathrm{CO}_{3}$ & $0,40 \mathrm{~kg}$ & Rp. $\quad 500,-$ & $200,--$ \\
\hline 10. & $\mathrm{NaHCO}_{3}$ & $0,86 \mathrm{~kg}$ & Rp. $\quad 500,-$ & $430, \ldots$ \\
\hline 11. & Cat Anilin & $0,43 \mathrm{~kg}$ & Rp.25.000,- & Rp.10.750,-- \\
\hline 12. & $\begin{array}{l}\text { Sulfonated } \\
\text { Neatsfoot oil }\end{array}$ & $1,29 \mathrm{~kg}$ & Rp. $3.500,-$ & Rp. 4.515,- \\
\hline 13. & $\begin{array}{l}\text { Unsulfonated } \\
\text { Neatsfoot oil }\end{array}$ & $0,43 \mathrm{~kg}$ & Rp. $4.000,-$ & Rp. $1.720,--$ \\
\hline 14. & Casein powder & $12,88 \mathrm{~kg}$ & Rp. 7.650,- & Rp.98.532,-- \\
\hline 15. & $\mathrm{NH}_{3}$ & $4,29 \mathrm{~kg}$ & Rp. 1.250,- & Rp. $5.362,50$ \\
\hline 16. & Enkanol Oil & $4,29 \mathrm{~kg}$ & Rp. $4.000,-$ & Rp.17.160,-- \\
\hline 17. & Formalin & $4,29 \mathrm{~kg}$ & Rp. $3.000,-$ & Rp.12.870,-- \\
\hline & & & & Rp171.794, \\
\hline
\end{tabular}

a. Bahan kimia.

Jumlah kebutuhan bahan kimia dalam sehari $=$ Rp.171.794,75.

Jumlah kebutuhan bahan kimia dalam 1 tahun $=$ $288 \times$ Rp. $171.794,75=$ Rp. 49.476.888, -

Jumlah kebutuhan bahan kimia dalam 3 bulan $=$ Rp. 12.369.222,--

b. Harga bahan pembantu proses $=$ Rp.11.500,-/hari Kebutuhan bahan pembantu proses dalam 3 bulan $=$ Rp.828.000,--

Kebutuhan bahan pembantu proses dalam 1 tahun = Rp.3.312.000,--

6. Instalasi Listrik.

Beaya pemasangan listrik. 


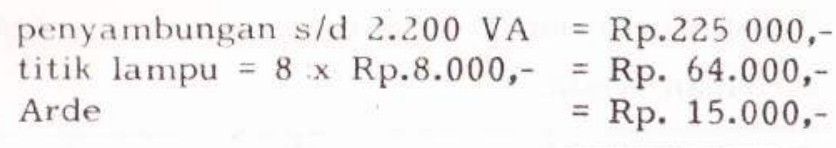

Rp.304.000,-

Rekening listrik = Rp. 43.034,624/bulan Rp.516.415,488/tahun

7. Air.

Kebutuhan air 3.000 lt/hari @ Rp. 0,50.

Harga kebutuhan air/hari = Rp. 1.500,--

$=$ Rp.432.000,--/tahun

8. Jumlah pegawai dan gaji.

No.

Jenis Pekerjaan

Jumlah Gaji/bulan

1. Manager/pemilik

1 orang Rp. 200.000 ,-

2. Tenaga pencucian, pengapuran, bu ang sisik, buang daging, buang $\mathrm{ka}^{-}$ pur, pengikisan protein, pengasam an dan penyamakan khrom

3. Tenaga aging, pencucian, penetral 3 orang Rp.180.000,an, pengecatan dasar dan penggemukan, pementangan, pengampelasan, pemotongan tepi, pengkilap an, penyeterikaan, pengaturan dan pengemasan

4. Operator / tenaga teknik

1 orang Rp. 72.000 ,-

Rp.632.000,-

Jumlah gaji per bulan $=$ Rp. $\quad 632.000,-/$ bulan

= Rp. 7.584.000,-/tahun

9. Peralatan.

Jumlah harga peralatan $=$ Rp. 3.502.750,--

\section{RINGKASAN}

Pabrik penyamakan kulit buaya samak khrom skala kecil dirancang untuk memproduksi kulit jadi dari kulit buaya sebagai bahan baku untuk membuat barang-barang kulit dari kulit buaya (tas, dompet, ikat pinggang dll).

Dengan trial and error yang disesuaikan dengan peralatan yang telah dirancang terlebih dahulu didapat grafik procentase break even point dengan kapasitas produksi 10 lembar/hari.

Pabrik direncanakan bekerja

Proses produksi

Jumlah tenaga kerja

Luas tanah $=480 \mathrm{~m}^{2}$, luas bangunan

Harga jual kulit buaya samak khrom

$=288$ hari/tahun

= samak krom

$=8$ orang

$=240 \mathrm{~m}^{2}$

$=$ Rp.66.000,-/lembar

Perhitungan ekonominya didapat sebagai berikut :

Kapasitas produksi 10 lembar/hari kulit buaya basah garaman

- Modal tetap

- Modal kerja, untuk 3 bulan

- Total modal

- Beaya tidak tetap

- Beaya tetap

- Total beaya produksi

- Harga pokok

- Hasil penjualan per tahun

- Keuntungan sebelum pajak

- Keuntungan sesudah pajak

$=$ Rp.109.787.425,-

= Rp. 28.362.325.78

$=\mathrm{Rp} \cdot 138.149 \cdot 750,78$

$=\mathrm{Rp} \cdot 105.865 .303,48$

$=$ Rp. $34.250 .609,89$

$=$ Rp.140.115.913,40

= Rp. $\quad 48.651,36 /$

lembar

$=$ Rp.190.080.000,-

= Rp. 49.964.086,60

$=$ Rp. $39.971 .269,30$

- Prosentase keuntungan untuk pengembalian modal.

- sebelum pajak $\quad=36,17 \%$

- sesudah pajak

$=28,93 \%$

- Waktu pengembalian modal

- sebelum pajak

- sesudah pajak

- Nilai batas rugi laba

- Prosentase batas rugi laba

- Kapasitas batas rugi laba

$=2$ tahun 8 bulan

$=3$ tahun 3 bulan

$=$ Rp. $77.306 .648,33$

$=40,67 \%$

$=1.171$ lembar

Catatan: harga berdasarkan tahun 1985. 